Original Article

\title{
Challenges of space and place for corporate 'citizens' and healthy mining communities: The case of Logan Lake, BC and Highland Valley Copper
}

\author{
Mary Louise McAllister ${ }^{\mathrm{a}, *}$, Patricia Fitzpatrick $^{\mathrm{b}}$, Alberto Fonseca ${ }^{\mathrm{c}}$ \\ a Environment and Resource Studies Department, University of Waterloo, Waterloo, ON N2L 3G1, Canada \\ ${ }^{\mathrm{b}}$ Department of Geography, University of Winnipeg, Winnipeg, MB R3B 2E0, Canada \\ ${ }^{\mathrm{c}}$ Department of Environmental Engineering, School of Mines, Federal University of Ouro Preto, Morro do Cruzeiro, Ouro Preto, MG 35400-000, Brazil
}

\section{A R T I C L E I N F O}

\section{Article history:}

Received 3 December 2013

Received in revised form 13 April 2014

Available online xxx

\section{Keywords:}

Corporate social responsibility (CSR)

Corporate citizenship

Logan Lake BC

Highland Valley Copper (HVC) Mine

Place-based governance

\begin{abstract}
A B S T R A C T
Considerable resources have been invested by global mining companies in corporate social responsibility (CSR) activities without a clear understanding of whether they are meeting their goals of sustaining affected communities long after a mine closes. It is argued here that effective 'corporate citizenship' (which is one way of viewing CSR) requires a deeper and extended understanding of what is implied by 'citizenship' in the context of issues of transparency, accountability, responsibility and community engagement. This reframing of CSR is explored through the case study of Logan Lake, British Columbia, Canada. The town is situated adjacent to the Highland Valley Copper (HVC) Mine. Case study research and analysis of this town suggests that the company's approach to CSR has generated a measure of good will within the community. Findings also reveal, however, that the town faces notable challenges with respect to the provision of health and social services despite a strong sense of community and attractive physical attributes. This paper suggests that effective 'corporate citizenship' practices might be better realized through participation in a regional 'place-based governance' strategy along with rural and remote communities that have often been marginalized by dominant political and economic interests.
\end{abstract}

(c) 2014 Elsevier Ltd. All rights reserved.

\section{Introduction: exploring the terrain}

Logan Lake, a Canadian mining town in the interior of British Columbia, belies 'frontier' town stereotypes even though the municipality contains one of the world's largest open pit copper mines: Highland Valley Copper (HVC). The well-planned town contains tidy homes, a strong sense of community, picturesque views and modern infrastructure. In many ways, it can be viewed as a contemporary 'model' community adjoining a progressive 'model' mining operation.

Despite such impressions, Logan Lake is subjected to many of the same external challenges that confronted mining communities a century ago. Located on the peripheries of the nation's consciousness, mining towns continue to be buffeted by 'cyclonic' international forces-a process first noted by economic historian Harold Innis in the early 1900s as he paddled his way through the

\footnotetext{
* Corresponding author. Tel.: +1 519888 4567x35614.

E-mail addresses: mlmcalli@uwaterloo.ca (M.L. McAllister), p.fitzpatrick@uwinnipeg.ca (P. Fitzpatrick), albertof@em.ufop.br (A. Fonseca).
}

remote regions of Canada (Lower and Innis, 1936). Notwithstanding these enduring challenges, the Canadian mining industry is no longer a hand-wielded 'pick-and-shovel' enterprise of the kind that Innis would be most familiar in his travels. Today, the industry relies heavily on advanced information and transportation technologies for both operations and decision-making processes expanding both the scale and scope of its activities. Mining operations can be massive in terms of volume of ore extracted and the economic returns accrued.

This is certainly the case in British Columbia and in Canada more generally given that the country is a world leader in mineral production. Primary resource development has been facilitated by a rich mineral endowment, technological innovation, and cooperative governments in their pursuit of revenues. Transnational corporations continue to grow in scale with each successive merger and acquisition. Over the decades, head offices have relocated from the resource community to provincial capitals or even offshore locations. This mobility of capital and senior mining executives represents a deepening and extending of an inexorable process that distances the physical location of corporate decisionmaking from those communities most directly affected. In marked 
contrast to investment capital, established base metal miningdependent communities such as Logan Lake are fixed in place and invariably located in remote locations. The ability of these towns to sustain themselves is compromised given governments' growing reliance on global corporations for the provision of community assistance through voluntary measures. In short, mining towns are fixed in place in an era of mobile labour and mining capital, and a global tightening of social-economic and political interdependencies. In this rapidly-shifting environment, corporations, governments and communities are often uncertain of both their rights and responsibilities when it comes to determining the scope and scale of corporate social responsibility (CSR). It is important, therefore, to explore what the term actually means in practice and whether it can meet its stated goals, specifically those related to one intended outcome-that is, helping to sustain affected communities. The following analysis considers the effectiveness of CSR in the context of a mine operation and community: namely, Teck Resources' HVC Mine and the Town of Logan Lake. Before its effectiveness can be assessed, it is first important to explore what constitutes 'good corporate citizenship'. To date, the mining corporation has advanced CSR through various community development initiatives and by developing indicators to assess its progress. It is argued here, however, that corporate citizenship could foster community sustainability more effectively if this company (and others like it) adopted a deeper understanding of what is implied by the term 'citizenship' with respect to questions of responsibility, accountability, transparency and community engagement. In addition, the corporation and senior levels of governments could participate in a regional place-based governance strategy thereby helping to reinforce the resilience of local communities that have often been marginalized by dominant economic and political interests. A place-based governing strategy emphasizes the importance of sense of place to local communities and the part it plays in building social capital and local capacity. Such an approach capitalizes on local knowledge, networks and collaborative approaches between affected interests and actors (Bradford, 2005).

\section{Diverse responsibilities and uncertain futures: companies and mine towns}

In the 21 st century, governments increasingly rely on corporate voluntary initiatives to ensure the continued well-being of communities affected by mineral operations. This has been a subject about which much has been written; (some recent examples include Bebbington, 2008, 2012; Fitzpatrick et al., 2011; Fonseca et al., 2013; Hilson, 2006; Hilson and Haselip, 2004; McAllister et al., 2014). Each strategy employed, as well as its perceived effectiveness, will differ as a result of many factors including the company's overall corporate philosophy and CSR strategy; the nature and type of the operation (e.g. open-pit vs. underground or long-distance, fly-in operations vs. mines operating proximate to towns); the relationship between the company and perceived affected communities; and the duration of the mine life-cycle. Each situation is very context specific. Nonetheless, there are some overarching questions surrounding this approach. If a corporation is to act as a good 'corporate citizen', to what community of interest is it responsible? Would it be to the residents of the nearest and first mining town associated with the mine, such as Logan Lake? Should a temporallybased principle of first occupancy be applied instead in order to recognize the rights of the indigenous people who inhabited the land long before a mine had ever been considered? What benefits should be provided to those communities where mine employees and their families reside and where mine-related business activities take place? What claims can be made by all those interests affected by the socio-economic and bio-physical 'shadow' impact of the mining activity-an impact that goes far beyond the immediate effects of operations at the mine site?

The ability of mining communities to sustain themselves into the future is compromised by competing interests of a growing multiplicity of actors that can legitimately stake a claim to the social-economic benefits accrued from mining operations. Despite, or perhaps because of, the uncertainties and harsh realities of a 'boom and bust' industry, the culture and tradition of mining communities can be surprisingly strong and enduring with inhabitants' possessing a strong sense of place (Markey et al., 2006). Over the years, mining communities have attempted to achieve some autonomy by diversifying away from single-industry dependence in order to develop buffers against the vagaries of external variables beyond their control. This process-one that has been encouraged by both corporate and State actors-may be viewed by some proponents as an exercise in promoting local selfgovernance, autonomy and subsidiarity. There is some validity in that perspective. An alternative view, however, would suggest that responsibilities have been off-loaded onto communities that have neither sufficient resources nor authority to carry them out.

Modern mining companies are motivated by the same set of economic drivers that have historically been the case, although those goals may now be presented through an enlightened selfinterested model of CSR which considers the perspectives of a wider range of stakeholders in decision-making processes. As a result of such efforts, a company may achieve some measure of a 'social license to operate' (Prno and Scott Slocombe, 2012). It is debatable, however, whether or not a company should, or would want to, also lay claim to the title of corporate 'citizen' given that the term implies consideration not only of rights but also some weighty responsibilities that they may see as beyond their corporate mandates (Néron and Norman, 2008). Nevertheless, companies, international organizations, and industrial associations frequently use the term to justify their activities in a community (e.g. Teck Resources Ltd, 2009; World Economic Forum, 2013). As noted above, one such company, Teck Resources Ltd., runs the massive open pit HVC operation and has been cited as setting an industry standard for global sustainability practices (Canadian Mining Journal, 2012). The operation and the affected mining Town of Logan Lake, therefore, offer an excellent case study to investigate how the town is affected by the operation itself and the company's implementation of CSR.

\section{Corporate social responsibility and citizenship: responsibility, accountability, transparency and community engagement}

Corporate social responsibility first emerged in various forums in the 1960s in order to combat growing public concerns about industrial bio-physical environmental impacts and address power imbalances between corporate and general public rights and interests (Carroll, 1999; Logsdon and Wood, 2002:157). Over a decade ago, Logsdon and Wood (2002) noted that the term "corporate citizenship" was introduced into the popular lexicon under the rubric of CSR and used as a "narrow, voluntaristic concept of community relations and philanthropy" (Logsdon and Wood, 2002:158). Citizenship as a term, however, implies more than a narrow focus on philanthropy; it includes expectations of both rights and responsibilities on the part of the citizen that would contribute to the collective well-being of the community (Logsdon and Wood, 2002:163).

What is the nature of a company's responsibility to the community and how far should that responsibility extend? One distinction between the terms corporate social responsibility and corporate citizenship is that the former refers more to a voluntary or discretionary activity, while corporate citizenship is obligatory and 
is viewed as an 'integral' part of corporate operations (Hamann et al., 2003). Corporate citizenship "Identifies the important role of local livelihoods, the right to prior informed consent to developments, access to information and access to justice" (Hamann et al., 2003:41). A significant body of literature discusses the legal rights of corporations as citizens but, for our purposes here, we focus on how companies acting as 'corporate citizens' might interpret their responsibilities towards mining-affected communities. Some analysts suggest that corporations are not formally citizens with respect to political rights as such a term of 'corporate citizen' may imply but they, nonetheless, should behave in "meaningful ways similar to that of citizens" (Moon et al., 2005:432). As noted earlier, citizenship, metaphorical or otherwise, implies both rights and responsibilities. Corporations actively assume the right to lobby and participate in the shaping of government regulatory activities. The Mining Association of British Columbia, for example, was established through a provincial act of legislation in 1901 to represent the provincial industry's interests and to "liaise with government legislators, lobby for regulatory advancement and publicly promote the economic and social value of mining" (Mining Association of British Columbia, 2013). Similarly, companies such as Teck Resources also participate in public policy and regulatory initiatives (Teck Resources Ltd, 2013a:27). Corporations, therefore, have shaped the fabric of the Canadian social, political and biophysical environment; this is certainly the case with HVC with its huge open pit operations slated for further expansion. The Town of Logan Lake was built to serve the mine, and the mining companies are generally viewed as having responsibility for their impact and legacy on a community (International Council on Mining and Metals, 2003; 2013). Mining operations reshape existing socio-ecological systems at various scales often creating novel ecosystems in the process. Given that reality, meaningful engagement as a corporate citizen would suggest that these companies are also obliged to assume a share of responsibilities commensurate with the rights they assume when undertaking their political, economic and industrial activities. Moreover, they are political actors of some significance and as such are obliged to be transparent and accountable with respect to their activities. It is this 'extended perspective' of corporate citizenship that is being applied here in this article (Crane et al., 2008). Beyond those broad obligations about what should accompany a claim to corporate citizenship, there are many contestable aspects about what this might entail in practice.

First, should these obligations be subject to a minimalist or an expansionist interpretation of corporation as responsible citizen (Néron and Norman, 2008:3)? Is it a matter of just doing 'enough' to achieve what is deemed to be a social license to operate within a community? The problem here is that there is no agreed-upon criteria that determines when or how a social license is to be granted (Prno and Scott Slocombe, 2012). Nevertheless, it is a widely-accepted principle throughout the mining industry that companies have an obligation to maintain and promote the social and biophysical health of the region affected by their operations (Shandro et al., 2011).

Second, to whom is the corporation responsible? This question raises considerations of space and place. Are global corporations "citizens of the world" where their activities are to be carried out in a consistent and equitable manner throughout all their operations at all scales? While that might be ideal, it has also been noted that "this view is more compatible with the universal ethical principles perspective on citizenship, but it does not go far enough in recognizing complex responsibilities that may legitimately differ from place to place" (Logsdon and Wood, 2002:172 italics added). To be meaningful, those initiatives must respond to the unique needs of the affected region. Yet, the diversity of these regions also makes it difficult to hold corporations to the same standards throughout their global operations. Most, if not all, large corporations do acknowledge that they are responsible to multiple constituents ranging from local to national interests.

Third, to be accountable, voluntary initiatives must be transparent. Members of the industry support the concept of transparency through their adoption of Principle 10 of the International Council on Mining and Metals (ICMM). Specifically, companies are expected to "Implement effective and transparent engagement, communication and independently verified reporting arrangements with our stakeholders" (International Council on Mining and Metals, 2003). It is also a tenet of the Extractive Industries Transparency Initiative (EITI) aimed at having companies publicly reveal how much of their revenues is contributed to a government-a process which can also serve to enhance the company's reputation as an important economic contributor (EITI International Secretariat, 2013). Theoretically, it could also help a community to hold a national or provincial government accountable for the distribution of resource revenues. That would be the case, however, only if the community had the leverage to do so. Given the need to tailor programmes to specific communities, however, detailed reporting for comparative purposes can be tricky logistically. Corporations prefer to undertake voluntary initiatives directed at the needs of the local region as opposed to being subjected to blanket, wide-sweeping provincewide regulations that may be costly for the company, inappropriate to the mine site, and ineffective in fostering social-ecological sustainability in the affected region.

Fourth, use of the term corporate citizenship would imply a company's pro-active engagement in active partnership with communities, not simply as a philanthropic donor to various causes when the community comes knocking at the door. CSR or corporate citizenship does not just call for accountability to the provincial and federal governments but to the local government and its citizens as well. Community leaders would be included in decision-making processes respecting the mine and to have input into the inevitable trade-offs that come when making decisions about an operation that has huge social and biophysical impacts.

This is where the principle of subsidiarity increasingly comes into play. This principle suggests that authority and responsibility should be handed down to the smallest unit of government that can deal with the task most effectively. Although most frequently associated with the European Union (Panizza, 2008), it is a principle that is gaining salience more universally where communities are included in decision-making processes. They are seen as having a stake in the outcomes of resource development, as well as having a right to help determine how that development takes place. This approach represents a significant departure from the politics that characterized the early company-owned towns a century ago. At that time, a community's affairs were largely governed by the mine owners and managers who lived on site and had a personal stake in the community and its well-being (Lucas, 1971). Today the primary actors in the mineral resource sector have expanded in both numbers and geographic locations. Corporate head offices are now a long distance from the mine site. Even the mine managers, the miners and the labour union representatives may not live in the local community. Affected parties that claim to have a vested interest in the mine include various industrial groups, the federal and provincial governments, environmental non-governmental organizations, Aboriginal peoples, unions, and nearby communities. Recognition of the right of a diversity of players to participate in decision-making processes from the local to the global has served to both enhance and diminish the leverage and the authority of the directly affected mining community. Moreover, local governments ${ }^{1}$

\footnotetext{
${ }^{1}$ Local governments referred to here should be distinguished from local Indigenous or Aboriginal communities which are typically governed through a
} distinctive set of constitutional arrangements with the State. 
typically fall under the constitutional jurisdiction of a state or province, which leaves them in weak negotiating positions. Subsidiarity as a principle, however, does reinforce the right of local governments to hold a position at the table when it comes to developing an effective CSR strategy.

In sum, the nature of the responsibilities implied in CSR and citizenship continues to be highly contested. If the corporate initiatives are to be seen as legitimate they must be viewed as being even-handed in terms of their global activities, while at the same time able to respond effectively to site-specific local demands and needs where mining operations take place. Moreover, they need to undertake these activities in a way that is not only transparent in practice, but widely perceived by the interested public as being transparent. Corporations must also be seen to actively engage with communities in order to foster capacity-building. Philanthropic activities (e.g. making contributions to a local event) may buy some short-term good will, but do little to support sustainable community development. The HVC mine has a fairly sophisticated strategy in place that addresses these points. For Logan Lake, however, the most directly affected town by its operations, there is still a measure of uncertainty which could be mitigated with a more coherent and integrated approach to local-level sustainability.

\section{Local perspectives: impacts of Highland Valley Copper on the town of Logan Lake}

The methodology is based on a single case study approach frequently used in community-oriented research (Evans, 2011; Yin, 2003). The theoretical propositions regarding the effectiveness of corporate citizenship and CSR initiatives discussed in the first part of paper are explored through an inductive analysis of the perspectives of community members. As is commonly practiced in community-based case study research, the researchers undertook some community-transect walks to get to know the spatial, physical and social elements of the community. Research participants were initially recruited through publicly available lists of government, private and community organizations followed by snowball sampling. Inevitably, the same people were often identified by various residents as being leaders in Logan Lake representing different communities of interest including local government, labour, civil society, citizens and industry. In terms of representation, we interviewed people who interacted with, or represented, the major demographic groups comprising the community in order to ensure that we included a diverse sample of the population. They included social, youth, health care, volunteer, and community outreach workers and representatives, among others, with their ages ranging from retirees to young adults. One limitation was that no research participants were included that would be considered economically or socially marginalized so their views were not directly represented. That said, concerns about their challenges and limited opportunities were raised by others during the course of the field work. Participants were specifically questioned about if, and how, the corporation acted in a socially-responsible manner particularly with respect to ensuring the well-being of the affected mining community, namely the Town of Logan Lake.
As mentioned above, the study adopted a single case study methodological approach in order to understand the contextual local conditions in which corporate voluntary measures were taking place (Yin, 2003:13). Investigator triangulation (Evans, 2011) was ensured with the use of a diversity of sources; the researchers collected national, provincial and local data through extensive literature and document reviews, undertook 13 semistructured interviews were collected, informally and conducted one focus group meeting held with community leaders. The quantity of participants and their profiles are presented in Table 1. Participants were assigned a code name, and unless given specific direction, we kept responses confidential. The industry representatives in Vancouver and at mine site, a union representative located in nearby City of Kamloops, and community leaders (working in the public or private sector as well as a retired community volunteer) were all open to questions. Furthermore, after several individual meetings, community leaders from Logan Lake invited the researchers to follow up in group discussions, one in a formal, and another in an informal, setting. In addition, the researchers took advantage of a well-designed, publicly-available tour of the mine site's operations. Given the small size of the town, we've limited the descriptions of individual positions and associated codes to ensure anonymity of the research participants with the exception of a couple of cases where the individual gave permission to have the position revealed.

Specific questions about operations posed to the participants varied according to whether they were members of community, mine representatives or government. Some of the questions, however, were posed to all participants, specifically those relating to the main animating research questions and sub-questions: namely the role of CSR and corporate citizenship with respect to questions of responsibility, accountability, transparency and community engagement. In particular, we wanted to investigate how research participants interpreted the role of the company (HVC) as corporate citizen in terms of sustaining local communities, as well the main challenges and/or successes and impediments to fulfilling that function.

\subsection{The town of Logan Lake}

November 1971 saw the official inauguration of Logan Lake, a town designed to provide a workforce for the newly opened Lornex copper mine in the Highland valley of south-central British Columbia. Since that time, the mine has grown into one of the largest copper operations in the world. The current mining operation known as HVC owned by Teck Resources Ltd. is located $15 \mathrm{~km}$ west of Logan Lake. This town, which had 2073 residents in 2011, is still heavily dependent economically on the mining company with 250 mineworkers and their families living in Logan Lake. The company's regional procurement of goods and services is also important to Logan Lake and other nearby communities. A number of retired mineworkers also live in the town. The majority of the rest of its 1230 mineworkers live in nearby communities such as Ashcroft, Kamloops, and Merritt, as well as some others (District of Logan Lake, 2013). The local mineworkers union (USW 7619) is also located in Kamloops. Limited social, health and recreational services in Logan Lake encourages residents to go to

Table 1

research participant profiles.

\begin{tabular}{|c|c|c|}
\hline Group & Interviewee profile & No. \\
\hline Mining industry & Senior company and industry association representatives & 3 \\
\hline Union representative & Long-term local representative (located in Kamloops) & 1 \\
\hline Local community members and leaders & Diverse representatives of local communities of interest & 6 \\
\hline Economic development representatives & Individuals who work in economic development both public and private sector & 3 \\
\hline
\end{tabular}


the larger centres such as the City of Kamloops so that people can participate in sports leagues and make use of the public services. At the time of writing, mine closure was scheduled for 2025. The community is working at diversification in anticipation of the closure and is focusing on being seen as a destination for outdoors tourism and retirement living. As one interviewee noted, the slogan for the town was "Logan Lake, where recreation and nature meet" (Participant 3).

When the HVC mine was initially slated for closure in 2009, the town marketed itself as a retirement community. At that time, the company, in cooperation with the community, set up a committee to deal with the implications of the closure. Subsequently, it was announced that the mine life would be extended until 2025 and almost $1 / 2$ billion dollars would be invested into a five-year mill expansion. The mill expansion and mine extension also stimulated employment and growth in a town that was rapidly declining in terms of population. According to one research participant, a community development fund was also established which allowed the District to develop a new housing complex (Participant 1).

The large number of retirees and seniors in Logan Lake are increasingly dependent on the provision of social and health services. When interviewed for this study, community members were almost unanimous in stating that there were concerns related to insufficient health services and accessible senior's housing. The health centre services are very limited, subject to periods of closure throughout the week, and provided with only part-time staffing.

\subsection{Teck resources' Highland Valley Copper mine}

The HVC mine is one of the world's largest copper mines in terms of biophysical scale and social implications. Given its size, it dwarfs any other economic enterprise in the area, particularly with respect to the Town of Logan Lake. As of 2013, Teck owned 97.5\% interest in HVC, located in south-central B.C. The three giant open pit operations (Valley, Lornex and Highmont) produced 116,300 t of copper in concentrate and 10.0 million pounds of molybdenum in 2012. Planned expansion of open-pit operations and a mill modernization programme to improve recovery will see considerable growth in output through the anticipated mine life of 2027 (Teck Resources Ltd, 2013b). In 2012, the HVC mine generated $\$ 390$ million after depreciation and amortization of \$123 million (Teck Resources Ltd, 2013a) For all of its Canadian operations, Teck paid \$264 million in income and resource taxes in 2012 excluding other taxes such as property, payroll, royalty, etc. (Teck Resources Ltd, 2013a). The company also pays municipal taxes. The company states that it aims to donate $1 \%$ of its annual pre-tax earnings to community investments (on a five-year rolling average basis). Worldwide, this figured reached a total of $\$ 23,192,000$ in 2012 , $\$ 16,481,000$ distributed through corporate offices. (Teck Resources Ltd, 2013a:35). In HVC, this amounted to $\$ 716,000$ in 2012 (Teck Resources Ltd, 2013a) excluding business-related donations such as sponsored events or scholarships.

The open pit operations of HVC impacted several lakes with the construction of tailing ponds. Over the years, notable efforts have been made to rehabilitate the areas affected by the open pit operations and the Corporation has invested in ecological restoration focusing on such things this fish spawning grounds and development of wetlands. Money for rehabilitation comes from the Highland Valley Enhancement fund. Donations from the mine funded a variety of recreational opportunities such as a ski hill operation and a rehabilitated tailings pond that is now stocked for fishing-all of which enhances tourism (Participant 2).

From a health perspective, a number of residents when interviewed noted that the only air quality problems they had observed was coming from forest fires in Siberia, not the nearby mine because of the nature of the prevailing wind patterns. They also pointed out that there had previously been problems with dust from the mining operation but, as a result of pressure from various constituencies, the mine invested in dust covers for their stock piles at the mill. That initiative appears to have resulted in a large improvement in the air quality (Participants 1,2,3). Beyond those comments, the community members did not voice concerns about biophysical impacts. While the topic did come up during the interviews, participants favourably mentioned the mitigation initiatives the company had taken towards ecological restoration. One long-term resident stated, "I think they're doing a heck of a job with their reclamation and whatever and environmental issues. Mining is dirty. There's noise, blasting disturbs things but that's the nature of the beast. But I think they're doing a good job on it myself" (Participant 2). All interviewees residing in Logan Lake made similar comments, some of whom had experience with other mining companies, and thought that HVC compared very favourably in this respect.

\subsection{Company and community perspectives on CSR and the HVC operation}

Under principles agreed to through ICMM and other internationally-established practices, companies increasingly are acknowledging the importance of their responsibility towards the long-term sustainability of affected mining towns. Considerations include the nature of company-community engagement, transparency, and social, economic and ecological impacts. Companies also acknowledge the importance of transparent communication of its impacts, activities and contributions which are often transmitted through company reports. The degree to which transparency is achieved through these reports, however, is a matter of continuing concern particularly given the diversity of reporting methods and lack of clarity at the level of each facility (Fonseca et al., 2013).

As noted above, in order to be responsive to the specific needs and requirements of mining-related communities, companies need to be aware of the context in which mining takes place. This is the case wherever CSR is practiced including at the HVC operations. When interviewed, the HVC mine manager agreed that there is no clear-cut idea for how to determine the specific manner in which CSR should be practiced in any given community. Much depends on the social political, economic and biophysical context. A paternal, benevolent approach to community development does not benefit the company nor the community in the long run. Donations are only "a momentary fix" and they create dependencies. The company would rather see the money go to community capacity-building. From the mine management perspective, the company is looking for opportunities that can most benefit the people and the community and the mine. "A big part of our focus is around that-developing opportunities that may start off linked with the mine but are external to the mine operations". Those company initiatives are not confined to Logan Lake:

Wherever we can promote those opportunities in nearby centres, we will. Kamloops and Merritt is a growing area of interest to us. We don't have as many of our new employees taking up residence in Logan Lake as we once did in the past. Some employees still do and certainly others are moving into Logan Lake as a retirement location. People also move to Kamloops and Merritt - we want to support those places where our workforce is (HVC mine manager).

One of the examples of capacity-building offered by the mine manager was a focus on the social and economic disparities in the area, such as those experienced by First Nations who "have been impacted by the operations but have more limited direct benefit from them". The company undertook the negotiation of an Impact Benefits Agreement with the nearby Nlaka'pamux First Nation 
(Teck Resources Ltd, 2013a). The mine representative stated that Teck looked for opportunities where it can make the biggest difference in the community. Although it does apply a social responsibility framework with key objectives developed by Teck at the corporate level, there is room for creativity locally.

Teck's commitment to CSR starts with the leadership at the CEO level (Participant 10). In part, Teck's CSR approach may be one associated with the history of the Canadian mining industry and it is one of the last Canadian giants left in this country. Canada had the first mining environmental policy in the world in the $1980 \mathrm{~s}$ followed up by the unique multi-stakeholder Whitehorse Mining Accord in the 1990s. Teck is acknowledged for its leadership in CSR policy and has been listed on the 2013 Dow Jones Sustainability World Index (DJSI), for the fourth year in a row, signifying that it ranks in the 10 per cent of the largest 2500 public companies worldwide (TECK Resources Ltd, 2013c).

With a couple of exceptions, research participants in the Town of Logan Lake appeared to be generally supportive of the CSR efforts of HVC (Participants, 1, 2, 3, 4 and 8) even though they were recruited from different communities of interest. The majority of them, however, acknowledged that Logan Lake, like many other isolated resource communities, faces challenges as it plans for the future. The town suffers from the lack of regular health care provision given its isolated position, and has concerns about youth-at-risk (Participant 4). Many participants were aware that health care is a provincial responsibility; negative comments about the provision of health services were frequently directed at the Interior Health Authority (IHA) and the provincial governmententities which were perceived to be failing at providing adequate services. That said, some community members who generally expressed serious concerns about the lack of health and social services were also aware that these problems are of direct relevance to the mining company, not just to the local community. One community member suggested that if more services were in place in Logan Lake, more mine employees and their families would stay in the vicinity instead of living away in Kamloops (Participant 8). A number of the town's retirees, including former mine workers, did not have local access to palliative care or any number of other services for seniors. This sentiment was also relayed in news articles that pointed out that with only limited emergency services available in Logan Lake, "residents have to schedule emergencies between 8 a.m. and noon. And, should there be a serious/life-threatening industrial accident at Highland Valley Copper, employees and contractors must take care to ensure it happens before noon" (Ogden, 2011). Emergency cases must be dealt with in the hospital in nearby Kamloops (60 km away) or Merritt (48 km away). Weather conditions for driving in the interior of B.C. can be treacherous, and mining can be a dangerous occupation. Moreover, one union representative argued that if workers are expected by the company to ensure safe practices as individuals, then companies and governments are responsible for the collective safety and well-being of mine workers (Participant 5 ). He felt that the corporate health and safety policy put the onus of responsibility on its workers whereby fines could be meted out when a health and safety incident occurred. As such, he says that it is difficult to encourage employees to come forward with information that would help ensure an accident would not happen again. He also worried that government reliance on corporate voluntary initiatives often led to a reliance on corporations to selfpolice which has its obvious limitations as a policy approach (Participant 5).

Beyond health care, most community members interviewed also expressed an overall positive impression of their relationship with HVC and how it dealt with their concerns and responded to requests for support for community fundraising initiatives. It was suggested by the union representative, however, that its members were also involved in participating in many of those volunteer activities-a point also made by other research participants (Participants 1, 2, 3, 4, 5 and 11). It was not clear to the researchers where these types of voluntary efforts of the mining corporation left off and those of the United Steelworkers (USW) -the minersbegan. Several participants suggested that the corporation tended to stay out of community affairs and associations, serving instead more as a corporate sponsor than participant.

As for how much corporate funding should go to Logan Lake and how much should be distributed elsewhere, one community member observed that mine employees were living in communities outside Logan Lake and that the company was expected to contribute resources to those communities as well (Participant 11). Community leaders generally thought that HVC was very responsive when it came to dealing with any adverse environmental impacts associated with the large operations, particularly compared to other mining companies. When asked why they thought that was the case, a number of interviewees offered that it may have something to do with the traditions that were passed down in Canadian-run mines, and of the social commitment of the mine management to the welfare of the local community:

I think it has a lot to do with the people they have in their management. They realize that. ..well, they live in the communities, too! A good big percentage of them live in Kamloops, they're in Merritt, they're in Logan Lake here, Ashcroft, all over. These people live in the actual community. What affects them, affects me, too. I don't know! You know, everything's not peaches and cream but it's an awful lot better than a lot of other places (Participant 2).

A somewhat alternative view about the company's community engagement was offered by one resident who felt that the company representatives should engage more actively in the affairs of the community rather than reactively operating more as "a donor rather than a citizen". Reflecting on past practices, this participant suggested that when members of mine management used to live directly in the community, the company was much more personally engaged with the overall well-being of the town (Participant 8). Along similar lines, a union representative suggested that Teck, as a global corporation, takes a 'cookiecutter' approach to policies when dealing with each of its mining operations throughout the world. It was also noted that the amount of money donated to the community was dwarfed in perspective when one thinks about the profits that the mine was generating (Participant 5).

In sum, the interviews revealed that community members were generally well-disposed towards the company and its responsiveness to their specific requests and concerns. That said, there were also some opinions expressed that the mine could take a more direct interest in helping the community deal with the provision of social and health services. Most of them also felt that it was quite transparent with respect to its operations and communications; the majority of participants noted as examples, company's regular freely-available tours of its operations and lots of publiclyavailable information. Notably lacking, however, was the feeling that the company was accountable or responsible to them, or was expected to act as a corporate citizen with a concomitant responsibility for the overall health and well-being of the community; rather it was seen more as a somewhat removed and benevolent source of funding for more specific projects.

\section{Mining the findings}

The fieldwork did provide insights into whether or not the company's CSR represented 'meaningful engagement' with the community with respect to its long-term sustainability. In 
response to the first question posed a the beginning of the piece, namely, whether Teck Resources Ltd. takes an expansionist or minimalist views of its CSR role, it is clear that the company sees itself as a corporate citizen although it does keep an arm's length distance from community decision-making. While some may see that decision as respecting the right of the community to govern itself without corporate interference, others might view it as not being as socially or personally invested in community well-being as it could be (as one research participant noted).

With respect to the second question dealing with corporate community responsibility, Teck's corporate sustainability report supported by interviews with company representatives clearly acknowledged a responsibility for promoting community wellbeing and to invest a portion of their profits back into the community. Beyond that, however, lines of accountability and responsibility of the corporation to the community(ies) remained unclear, and possibility necessarily so. Recognizing that each mining region has its own needs, cultures and requirements, the company takes a flexible approach in order to address specific community needs. In the case of HVC, rapid change and the growth of the mining enterprise were accompanied by an increasing mobility of labour, capital and services, as well as rising claims to compensation by a plurality of communities and groups that reached beyond the boundaries of the Town of Logan Lake.

Third, regarding the question of transparency in its operations, Teck Resources has signed on to the ICMM framework and has reported its sustainability contributions according to the Global Reporting Initiative (GRI) guidelines (for a discussion of this initiative, see Fonseca et al., 2012). In its sustainability report, initiatives at the local community level are often aggregated on a regional basis. This approach is consistent with a company strategy aimed at assisting those communities where its operations have an impact and its employees reside, and in both cases, that stretches beyond the boundaries of the Town of Logan Lake. The corporate sustainability report, however, does not provide the kind of subregional numbers that would allow for an informed comparative assessment of how voluntary funds from the corporation were distributed within a region. Individual community members also did not appear to have information about the nature of corporate donations contributed to other towns outside of Logan Lake.

The fourth question posed concerned the degree to which communities were able to participate in decision-making with respect to the nature of corporate voluntary initiatives and allocation of funds. The primary research seemed to suggest that the company was frequently supportive when the community had a request for assistance with a particular event or development. Community members, however, could not be characterized as partners in the decision-making regarding the overall allocation or distribution of the corporate voluntary funds. Both the primary and secondary research supported the conclusion that Teck Resources has invested a notable amount of time and resources towards achieving best practices in CSR. A certain measure of transparency of its operations has been achieved through its participation globally in the Extractive Industries Transparency Initiative (EITI), domestically by revealing its CSR expenditures and its use of indicators to assess progress, and locally by its responsiveness to community requests and concerns, and through regularly offered public information and tours of its mine site operations.

Despite these efforts, what does not appear to be happening is the effective empowerment of local communities by either the provincial government or the mining corporation when it comes to making decisions about issues that most directly affect these towns. Senior governments have acknowledged the presence of health, economic and social challenges specific to remote resource communities. Assistance packages are offered by agencies such as the Community Adjustment Fund, Western Economic Diversification Canada and the Northern Development Initiative Trust (Shandro et al., 2011) or through the provincial government (British Columbia Ministry of Community Sport and Cultural Development, 2013). Nevertheless, the 'boom and bust' nature of mining activities affects a town's fluctuating population numbers which, in turn, affects the type and extent of service provision offered by the provincial government, often falling far short of the requirements of the communities. This has been the case for Logan Lake and other resource communities (Shandro et al., 2011).

\section{From the ground up: applying the principles of subsidiarity and place-based governance}

Corporations are real members of some kind of our communities, the power to contribute to or to diminish the common good, and the right to influence political and legal processes. As any decent comic book superhero knows, with great power comes great responsibility (Néron and Norman, 2008:16).

A commitment to transparency suggests that members of the public should have information about a mine site's social and environmental impacts much the way citizens can gain access to city hall minutes and council meetings and to government information under the federal and provincial access to information laws. There is obviously a distinction between public and private sector information but the argument here is not that the public have access to a company's proprietary information. Rather, it is suggested that the public should have ready access to information about the mine that goes beyond what is required for 'social risk' management. If corporations wish to lay claim to the term good corporate citizen which includes transparency, then ready access to information about the company's activities should serve to reinforce, and not undermine, that claim. At times, as with government watchdogs, such scrutiny can be painful if the corporation fails to live up to its promises. However, claims to corporate citizenship inevitably ring hollow and can be met with widespread scepticism without open public access to information about daily operating procedures and practices. As yet, in even the best practices of CSR demonstrated at the HVC model mine, what appears to be missing is a concerted and transparent regional communications strategy that includes the communities of interest directly affected by a company's operations. The research participants from Logan Lake did not appear to have major complaints about HVC with respect to its approach to corporate social responsibility, which was generally interpreted narrowly: i.e. the company willingly provided support to local initiatives when requested. It was equally clear that town members had little knowledge of how the corporation implemented its CSR strategy with other nearby communities or at a regional level. As such, they were not able to participate in a discussion about how funds might be more effectively deployed on a region-wide basis.

Research of government documents and other secondary literature suggests that a different approach to CSR could be employed: one that would strengthen accountability of corporate, government and other influential actors in the decision-making processes as well as facilitate community engagement. Although there are government-led regional economic growth initiatives, community services, and regional health strategies, many of these initiatives are compartmentalized into policy categories, e.g. economic development, health care or some other 'silo'. We are suggesting a different approach here; that of place-based governance which recognizes the importance of social infrastructure and 'networks for democratic participation' (Bradford, 2005). Among other things, a place-based approach includes drawing on local knowledge, engaging in collaborative governance (between 
communities of interests and governments) and recognizing the key role that can be played by local governments (Bradford, 2005).

In the course of conducting the Logan Lake field work, it became apparent that all the affected communities of interest and towns were not working closely together towards a mutual understanding of their collective needs and challenges as well as opportunities posed by the large mining operation. Given the shared resourcebased history and geography, communities could benefit considerably by developing a collaborative place-based regional strategy. This approach draws on the work of Markey et al. They suggest that successful rural place-based development is a "collaborative and co-constructed approach" needed to "create viable communities that are economically robust, socially resilient, and environmentally sustainable" (Markey et al., 2012:4-5). This kind of strategy would be consistent with a philosophical view "[as] if we were building communities and regional economies of permanence and not simply treating the region as a resource frontier" (Markey et al., 2012:4-5).

Such a strategy could foster regional capacity-building allowing the area to become more resilient and less buffeted by the boombust characteristics of a resource-based economy. A transparent region-based communications strategy would first be required in order to develop a shared understanding about how Teck's CSR initiatives are distributed amongst the various communities and groups within the region. This would include the towns of Kamloops, Merritt, Logan Lake, Ashcroft, the small communities within that area, as well as First Nations. Affected communities of interest could then use that information to participate in a discussion about how they could work collaboratively to use these funds (as well as public funds) to address questions of overall regional health and social well-being.

Contemporary large mining corporations are not in the business of community development, nor do they want the responsibility for running mining communities; they appropriately view that responsibility as belonging to citizens and their elected governments. The proposed recommendation above, therefore, would be consistent with Teck Resources' (and other similar companies') aspirations of fostering transparency with respect to mine operations and community capacity-building. Under a place-based governance approach, it would be communities, not companies, determining the most effective and sustainable way forward for the collective whole.

\section{Conclusion}

As with any collective good, temptations exist for actors to shirk or hold back in hopes that other actors will incur the costs of achieving the collective good, which then benefits all actors (Olson, 1965 cited in Logsdon and Wood, 2002:181)

As noted in Section 1, it is argued in this paper that corporate citizenship could more effectively foster community sustainability if Teck Resources Inc. (and other such companies) adopted a deeper understanding of what is implied by the term 'citizenship' with respect to questions of accountability, responsibility and transparency and community engagement. Rather than the government imposition of blanket regulations that may not be very effective or efficient from a site-specific perspective, CSR allows for targeted approaches to the social and biophysical requirements of the affected regions. But the trade-offs should not come at the expense of local communities who lose agency, capacity and control over resources to make decisions that would allow them to thrive. Neither corporations nor governments want to be responsible for the rising social, health or infrastructural costs of a remote mining community. In such a scenario, these communities inevitably fall through the cracks.
With respect to the case study area, evidence supports the finding that Teck Resources, with its HVC operation, has worked to establish an effective CSR strategy. Company goals include fostering community sustainability, economic diversification, and transparent decision-making (Teck Resources Ltd, 2013a). This is a situation confirmed by the research participants in Logan Lake. While the community itself did not lobby for a different strategic approach from the company, its members still voiced concern about the future of its town and the lack of services, particularly for its ageing population. Achievement of the company's goals through the deployment of funds allocated through voluntary initiatives, however, will not be realized without a full collective partnership with the affected communities. Collaborative efforts are required at an inter-jurisdictional regional level to effectively address those issues common to resource-based communities. The direct impacts of large mining operations such as HVC have expanded far beyond the jurisdictional territory of a single community. Yet, many individual corporate voluntary initiatives still appear to be oriented towards a specific community or through targeted efforts.

A more systemic, regional place-based governance approach to corporate citizenship would see the distribution of corporate voluntary funds and initiatives disbursed through a communitydetermined process. Tangible results of such an effort could include effective inter-community transportation systems, and a collective approach to the delivery of emergency, health and social services. Less immediate benefits would be the strengthening of corporate and government accountability, community development and place-based governance supporting the stated goals of governments, corporations and other affected actors. At present, small resource-dependent communities have little leverage with respect to those forces that most directly affect them. Cooperation between communities supported by corporate funds earmarked for voluntary initiatives will strengthen their longer term resilience and survival.

\section{Acknowledgements}

The authors would like to thank the peer reviewers and the editor for their very helpful and intelligent suggestions. We would also like to acknowledge funding provided for this research from the Social Sciences and Humanities Research Council of Canada 410-2010-0258. Finally, we very much appreciate the warm welcome we received by the residents of Logan Lake (particularly those who generously shared their time for the interview process), as well as the open and helpful responses that we received from the representatives of Teck Resources Inc. and USW Local 7619. Any possible errors of misinterpretation are the authors' own.

\section{References}

Bebbington, A., 2008. Mining and social movements: struggles over livelihood and rural territorial development in the Andes. World Dev. 36, 2888-2905.

Bebbington, A. (Ed.), 2012. Social Conflict and Economic Development: Evidence from South America. Routledge, London.

Bradford, N., 2005. Place-based Public Policy: Towards a New Urban and Community Agenda for Canada, Canadian Policy Research Networks. Canadian Public Research Networks, Ottawa.

Canadian Mining Journal, 2012. Teck Resources Named to Dow Jones Sustainability World Index.

Carroll, A.B., 1999. Corporate social responsibility: evolution of a definitional construct. Bus. Soc. 38, 268-295.

Crane, A., Matten, D., Moon, J., 2008. The emergence of corporate citizenship: historical development and alternative perspectives. In: Scherer, A.G., Palazzo, G. (Eds.), Handbook of Research on Global Corporate Citizenship. Edward Elgar, Cheltenham, pp. 25-49.

District of Logan Lake, 2013. Logan Lake Visitor's Guide. District of Logan Lake, Logan Lake.

EITI International Secretariat, 2013. Extractive Industries Transparency Initiative: Stakeholders - Teck Resources. EITI International Secretariat, Oslo, Norway. 
Evans, R., 2011. Case study method in sustainability research. In: Franklin, A., Blyton, P. (Eds.), Researching Sustainability: A Guide to Social Science Methods, Practice, and Engagement. Earthscan, Washington, DC, pp. 54-70.

Fitzpatrick, P., Fonseca, A., McAllister, M.L., 2011. From the Whitehorse initiative towards sustainable mining: lessons learned. J. Clean. Prod. 19, 376-384.

Fonseca, A., McAllister, M.L., Fitzpatrick, P., 2012. Sustainability reporting among mining corporations: a constructive critique of the GRI approach. J. Clean. Prod.

Fonseca, A., McAllister, M.L., Fitzpatrick, P., 2013. Measuring what? A comparative anatomy of five mining sustainability frameworks. Miner. Eng. 46-47, 180-186.

Hamann, R., Acutt, N., Kapelus, P., 2003. Turning point: responsibility versus accountability? Interpreting the World summit on sustainable development for a synthesis model of corporate citizenship. J. Corp. Citizen. 32-48.

Hilson, G., 2006. Championing the rhetoric? "Corporate Social Responsibility" in Ghana mining sector. Greener Manag. Int. 53.

Hilson, G., Haselip, J., 2004. The environmental and socioeconomic performance of multinational mining companies in the developing world economy. Miner. Energy: Raw Mater. Rep. 19, 25-47.

International Council on Mining and Metals, 2003; 2013. Our Work: Sustainable Development Framework - 10 Principles.

Logsdon, J.M., Wood, D.J., 2002. Business citizenship: from domestic to global level of analysis. Bus. Ethics Q. 12 155-12187.

Lower, A.R.M., Innis, H.A., 1936. Settlement and the Forest Frontier in Eastern Canada by A.R.M. Lower Published Together with H.A. Innis, Settlement and the Mining Frontier. Ryerson, Toronto.

Lucas, R.A., 1971. Minetown, Milltown, Railtown; Life in Canadian Communities of Single Industry. University of Toronto Press, Toronto.

Markey, S., Halseth, G., Manson, D., 2006. The struggle to compete: from comparative to competitive advantage in Northern British Columbia. Int. Plan. Stud. 11, 19-39.
Markey, S., Halseth, G., Manson, D., 2012. Investing in Place: Economic Renewal in Northern British Columbia. University of British Columbia Press, Vancouver

McAllister, M.L., Fitzpatrick, P., Fonseca, A., 2014. Unstable shafts and shaky pillars: institutional capacity and sustainable mineral policy in Canada. Environ. Polit. 23, 77-96.

Mining Association of British Columbia, 2013. About MABC. Mining Association of British Columbia, Vancouver.

Moon, J., Crane, A., Matten, D., 2005. Can corporations be citizens? Corporate citizenship as a metaphor for business participation in society. Bus. Ethics Q. 15 , 429-453.

Néron, P.-Y., Norman, W., 2008. CITIZENSHIP INC.: Do we really want businesses to be good corporate citizens? Bus. Ethics Q. 18, 1-26.

Ogden, B., 2011. Mike DeJong Comes to Town Merritt-Herald, Merritt.

Panizza, R., 2008. The Principle of Subsidiarity, 2009th ed. European Communities.

Prno, J., Scott Slocombe, D., 2012. Exploring the origins of 'social license to operate' in the mining sector: perspectives from governance and sustainability theories. Resour. Policy 37, 346-357.

Shandro, J.A., Veiga, M.M., Shoveller, J., Scoble, M., Koehoorn, M., 2011. Perspectives on community health issues and the mining boom-bust cycle. Resour. Policy 36, $178-186$.

Teck Resources Ltd., 2009. Charter of Corporate Responsibility. TECK Resources Ltd.. Teck Resources Ltd., 2013a. Generations: Teck 2012 Sustainability Report.

Teck Resources Ltd., 2013b. Teck 100 Celebrating 100 Years: Annual Report 2012. Teck Resources Ltd., Vancouver Operations.

TECK Resources Ltd., 2013c. Teck Named to Dow Jones Sustainability Index, September 12 ed.

World Economic Forum, 2013. Global Corporate Citizenship.

Yin, R.K., 2003. Case Study Research: Design and Methods, 3rd ed. Sage Publications, Thousand Oaks, CA.

Please cite this article in press as: McAllister, M.L., et al., Challenges of space and place for corporate 'citizens' and healthy mining communities: The case of Logan Lake, BC and Highland Valley Copper. Extr. Ind. Soc. (2014), http://dx.doi.org/10.1016/ j.exis.2014.04.005 